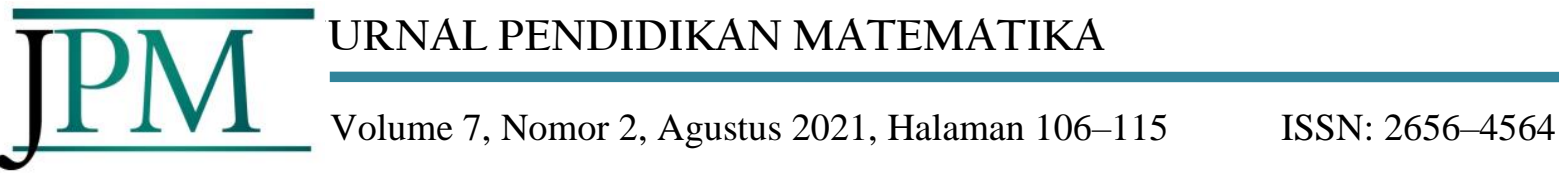

\section{IMPLEMENTASI PEMBELAJARAN DARING PADA MATA KULIAH STATISTIK BERBASIS VIDEO}

\author{
Nusrotus Sa'idah', Wulan Sutriyani ${ }^{2}$ \\ ${ }^{1,2}$ Universitas Islam Nahdlatul Ulama Jepara, Indonesia \\ nusrotussaidah@unisnu.ac.id ${ }^{1}$, wulan@unisnu.ac.id ${ }^{2}$
}

\begin{abstract}
ABSTRAK
Penelitian ini bertujuan untuk mendiskripsikan mengetahui respon mahasiswa dan efektifitas pembelajaran daring untuk mata kuliah statistic di lingkungan fakultas tarbiyah dan ilmu keguruan Unisnju Jepara. Sampel dari penelitian ini adalah mahasiswa dari fakultas tarbiyah dan keguruan Unisnu Jepara pada program studi pendidikan agama islam, pendidikan bahasa Inggris dan pendidikan guru sekolah dasar yang mengikuti mata kuliah statistik yaitu sebanyak 107 mahasiswa. Instrumen penelitian ini yaitu kuesioner tentang persepsi mahasiswa pembelajaran daring berbasis video yang disebarkan melalui googleform. Teknik analisis data pada penelitian ini menggunakan statistic deskriptif untuk mengungkapkan beberapa indikator respon persepsi mahasiswa terhadap pembelajaran daring mata kuliah statistic. Hasil analisis menunjukkan bahwa implementasi pembelajaran daring dengan menggunakan video yaitu aspek materi 3,77 (baik), aspek compatibility 3,59 (baik), kompleksitas 3,38 (cukup), aspek triability 3,51 (baik) dan aspek kebermanfaatan 3,6 (baik). Dengan adanya pembelajaran berbasis video ini upaya untuk memberi materi dalam bentuk tutorial video mempraktikkan analisis data dengan spss pada mata kuliah statistic.
\end{abstract}

Kata kunci: Efektivitas, Pembelajaran Daring, Statistik

\section{ABSTRACT}

This study aims to describe the student response and effectiveness of online learning for statistics courses in the Tarbiyah and teacher science faculty, Unisnu Jepara. The sample of this study were students from the faculty of Tarbiyah and teacher training at Unisnu Jepara in the Islamic religious education study program, English language education and primary school teacher education who took statistical courses, as many as 107 students. The research instrument was a questionnaire about student perceptions of video-based online learning distributed via google form. The data analysis technique in this study used descriptive statistics to reveal several indicators of student perceptual responses to online learning in statistics courses. The results of the analysis show that the implementation of online learning using video is 3.77 (good) material aspects, compatibility aspects 3.59 (good), complexity 3.38 (sufficient), triability aspects 3.51 (good) and usefulness aspects 3, 6 (good). With this video-based learning an effort to provide material in the form of video tutorials practicing data analysis with Spss in statistics courses.

Keywords: effectiveness, online learning, statistics

\section{PENDAHULUAN}

Proses kegiatan belajar mengajar di Universitas adalah kegiatan yang dilakukan dosen dengan memberikan pendidikan dan pelatihan kepada mahasiswa supaya hasil belajar mecapai hasil yang baik. Dengan munculnya wabah Covid-19 yang melanda dunia, berdampak terhadap proses kegiatan pembelajaran di seluruh Universitas termasuk Unisnu Jepara, dimana pembelajaran tidak dapat dilaksanakan secara tatap muka/ luring sehingga 
dosen harus menggunakan metode yang tepat dengan harapan hasil belajar mahasiswa dapat maksimal. Sehingga menuntut dosen untuk dapat melakukan penyesuaian dalam kegiatan pembelajaran dengan cara melakukan pembelajaran secara daring/online pada masa pandemi ini.

Pembelajaran daring merupakan sebagai salah satu kegiatan pendidikan formal yang dilaksanakan di Univesritas yang diselenggarakan oleh mahasiswa dengan dosen (instrukturnya) dengan posisi yang berbeda tempat atau terpisah jadi membutuhhkan sistem telekomunikasi interaktif untuk dapat menghubungkan keduanya sehingga kegiatan pembelajaran tetap dapat berlangsung.

Setiap pelajaran menyediakan materi dalam bentuk rekaman video atau slideshow, dengan tugas-tugas mingguan yang harus dikerjakan dengan batas waktu pengerjaan yang telah ditentukan dan beragam sistem penilaian (Bilfaqih, 2015). Hal tersebut dilaksanakan karena membatasi penyebaran virus Corona yang sedang mewabah saat ini.

Proses kegiatan belajar mengajar dari rumah diputuskan menteri pendidikan dan kebudayaan pada tanggal 9 Maret 2020 dengan mengeluarkan surat edaran No. 2 tahun 2020 dan No. 3 tahun 2020 yang berisikan tentang kegiatan pemebelajaran secara daring dan bekerja dari rumah dalam rangka mencegah penyebaran virus Corona yang mewabah saat ini.

Penggunaan teknologi informasi saat ini memiliki peran yang sangat penting terutama pada mata kuliah statistik, karena mata kuliah ini dianggap sulit bagi mahasiswa apalagi dengan pembelajaran daring dimana dosen menjelaskannya secara virtual oleh karena itu teknologi informasi merupakan salah satu media yang tepat digunakan untuk dapat tetap melakukan pembelajaran meskipun dalam lokasi yang berbeda, proses pembelajaran bisa berjalan dengan baik dengan adanya teknologi informasi yang sudah berkembang pesat saat ini seperti whatsapp group serta media infromasi lainnya serta jaringan internet yang dapat menghubungkan dosen dan mahasiswa sehingga proses belajar mengajar dapat berjalan dengan baik sebagai mana mestinya meskipun ditengah pandemi covid-19 (Pakpahan, R., \& Fitriani,Y., 2020).

Statistik merupakan salah satu matakuliah yang wajib di dapatkan mahasiswa selama satu semester. Mata kuliah statistik dianggap sebagai mata kuliah yang cukup sulit, karena mata kuliah ini termasuk dengan perhitungan angka-angka atau rumus-rumus yang aplikasinya harus dipelajari melalui langkah-langkah perhitungan yang cukup rumit khususnya bagi mahasiswa yang berbasis ilmu-ilmu sosial. Seorang dosen tidak jarang harus mengulang-ulang materi perkuliahannya karena beberapa mahasiswa masih kurang jelas terhadap materi yang disampaikan hanya dengan sekali di kelas. Statistik merupakan sekumpulan cara dan aturan tentang pengumpulan, pengolahan, analisis, serta penafsiran data yang terdiri dari angkaangka. Sehingga menuntut dosen untuk dapat menggunakan media yang tepat saat pandemi.

Media pembelajaran merupakan sarana ataupun instrumen yang dapat mendorong efektifitas dan efisiensi kegitanan pembelajaran, khususnya ketika mahasiswa diharuskan belajar dari rumah selama masa pandemi virus Corona (Haryadi, R., Vita, M., Utami, I. S., Ihsanudin, I., Setiani, Y., \& Suherman, 2019). Sehingga penggunaan media pembelajaran yang adaptif dan berkualitas sebagai salah satu cara untuk mewujudkan suasana belajar yang menyenangkan dan dapat meningkatkan hasil belajar mahasiswa (Batubara, H. H., \& Ariani, 2019). Salah satu media pembelajaran yang tepat digunakan dalam mata kuliah statistik selama masa pandemi yaitu penggunaan media video tutorial.

Video tutorial merupakan rangkaian gambaran hidup yang mampu menyajikan informasi yang diberikan oleh seseorang ahli atau tutor kepada sekelompok orang sehingga sekelompok orang tersebutmampu memahami proses atau menambah pengetahuannya hanya dengan melihat video tersebut (Utomo, 2018). Dengan video tutorial maka diharapkan matakuliah statistik yang dianggap sebagian besar mahasiswa sebagai matakuliah yang sulit diatasi, karena di dalam vidio tutorial langkah-langkah pengerjaan statistik yang cenderung 
rumit dapat dipelajari dan dipraktikkan secara langsung maupun tidak langsung yang sudah di posting dosen di salah satu teknologi informasi yang digunakan oleh dosen selama pembelajarean, misalkan lewat Whatsapp grup, Google Clasrom atau yang lain sebagainya. Dengan media video tutorial ini diharapkan hasil belajar matakuliah statistik untuk semester 4 di Unisnu Jepara Prodi PAI dan PGSD dapat meningkat. Mata kuliah statistik ini buka hanya pemahaman teori tetapi lebih pada penerapan bagaimana olah data penelitian dapat menjawab tujuan penelitian. Mahasiswa selalu kurang aktif kurang mencari tambahan diluar yang disampaikan oleh dosen (Irsyad et al., 2020). Permasalahan ini serupa sekali dalam penemuan penelitian masih banyak mahasiswa yang mengikuti perkuliahan hanya sekedar tahu materi tanpa memacu keaktifan dalam perkuliahan.

Dalam kaitannya dengan hasil belajar, pembelajaran jarak jauh masih menjadi polemik dikalangan stakeholder dan masyarakat. Dikarenakan pembelajaran jarak jauh ini masih di anggap tidak lebih baik daripada pembelajaran langsung secara konvensional terutama dalam pembelajaran statistik. Hal ini di disebabkan karena dalam mempelajari statistik mahasiswa harus mampu mengolah, menafsirkan dan menganalisis data yang terdiri dari angka-angka dengan aturan tertentu.

Berdasarkan hal tersebut, maka peneliti ingin mengetahui efektifitas dalam pengimplementasian media vidio tutorial terhadap hasil belajar mata kuliah statistik dalam masa pandemi Covid-19. Hasil penelitian ini dapat memperkaya data tentang pembelajaran jarak jauh (daring learning) yang berkaitan dengan hasil belajar mahasiswa.

\section{METODE}

Penelitian ini merupakan penelitian deskriptif kuatitatif untuk mengetahui respon mahasiswa dan efektifitas pembelajaran daring untuk mata kuliah statistic di lingkungan fakultas tarbiyah dan ilmu keguruan Unisnju Jepara. Sampel dari penelitian ini adalah mahasiswa dari fakultas tarbiyah dan keguruan Unisnu Jepara pada program studi pendidikan agama islam, pendidikan bahasa Inggris dan pendidikan guru sekolah dasar yang mengikuti mata kuliah statistik yaitu sebanyak 107 mahasiswa. Teknik pengambilan sampel penelitian menggunakan sampel jenuh uaitu dari keseluruhan populasi diambil untuk dijadikan sampel penelitian. Instrumen penelitian ini yaitu kuesioner tentang perepsi mahasiswa pembelajaran daring berbasis video yang disebarkan melalui google form. Teknik analisis data pada penelitian ini menggunakan statistic deskriptif untuk mengungkapkan beberapa indikator respon persepsi mahasiswa terhadap pembelajaran daring mata kuliah statistic. Berikut adalah kisi-kisi instrument respon mahasiswa dalam pembelajaran daring.

Tabel 1. Kisi-kisi Instrument Respon Mahasiswa Dalam Pembelajaran Daring

Indikator No Pernyataan

\begin{tabular}{lrl}
\hline Materi & 1 & Materi yang ditampilkan secara runtut pada video tutorial \\
\cline { 2 - 3 } & 2 & Ketepatan contoh materi kuliah pada video tutorial \\
\cline { 2 - 3 } & 3 & Menggunakan Bahasa yang komunikatif \\
\hline Compatibility & Ketepatan prosedur langkah analisis data statistik pada video tutorial \\
\cline { 2 - 3 } & 2 & Saya suka tampilan gambar pada video tutorial \\
& 2 & Saya suka kualitas audio video tutorial \\
\hline Complexity & 4 & Saya memahami prosedur materi statistic secara lengkap \\
& 1 & Saya memiliki alat pemutar video tutorial \\
\hline & 2 & Saya tidak mengalami masalah saat menggunakan video tutorial \\
\hline
\end{tabular}


4 Video tutorial ini termasuk media yang mudah digunakan dalam perkuliahan statistic

\begin{tabular}{lrl}
\hline Triability & 1 & Saya sudah terbiasa menggunakan video tutorial \\
\cline { 2 - 3 } & 2 & Saya dapat mencoba video tutorial statistic ini secara mandiri \\
\cline { 2 - 3 } $\begin{array}{l}3 \\
\text { Relative }\end{array}$ & $\begin{array}{l}\text { Saya dapat menggunakan video tutorial secara berulang-ulang pada } \\
\text { materi kuliah statistik }\end{array}$ \\
\hline 4 & $\begin{array}{l}\text { Video tutorial statisik ini sangat efektif digunakan dalam pembelajaran } \\
\text { di rumah }\end{array}$ \\
\hline 1 & Video tutorial statistic ini dapat meningkatkan pemahaman saya \\
\hline 2 & Video tutorial memperjelas materi perkuliahan statistik \\
\hline 3 & Video tutorial ini dapat membantu belajar mandiri saya \\
\hline 4 & $\begin{array}{l}\text { Video tutorial ini dapat membantu penyelesaian tugas mata kuliah } \\
\text { statistik }\end{array}$ \\
\hline 5 & Video tutorial dapat mengatasi belajar saya \\
\hline
\end{tabular}

\section{HASIL}

Pada penelitian ini mengimplementasikan video tutorial analisis data menggunakan Ms.Excell maupun IBM SPSS Statistics 20. Mata kuliah ini bertujuan untuk terampil menganalisis dan menginterpretasikan data penelitian menggunakan Ms.Excell maupun IBM SPSS Statistics 20. Penelitian ini dilakukan dengan menyebarkan kuesioner melalui google form untuk mengetahui respon mahasiswa terkait pembelajaran daring statistik dengan video. Berikut pemaparan hasil jawaban responden dari beberapa indikator.

Responden yang mengisi kuesioner ini terdiri dari mahasiswa prodi Pendidikan Agama Islam, Pendidikan Bahasa Inggris dan Pendidikan Guru Sekolah Dasar. Berikut profil dari respon mahasiswa yang mengikuti pembelajaran statistic menggunakan video.

Tabel 2. Profil Responden

\begin{tabular}{|c|c|c|c|}
\hline \multicolumn{4}{|c|}{ Profil Responden } \\
\hline No & Aspek & & Respon \\
\hline \multirow[t]{2}{*}{1} & Jenis Kelamin & Lk & $10 \%$ \\
\hline & & $\operatorname{Pr}$ & $90 \%$ \\
\hline \multirow[t]{7}{*}{2} & Usia & 18 & $2 \%$ \\
\hline & & 19 & $11 \%$ \\
\hline & & 20 & $52 \%$ \\
\hline & & 21 & $24 \%$ \\
\hline & & 22 & $5 \%$ \\
\hline & & 23 & $2 \%$ \\
\hline & & 24 & $4 \%$ \\
\hline 3 & Kepemilikan smartphone & & $100 \%$ \\
\hline \multirow[t]{2}{*}{4} & Kepemilikan Laptop & $\mathrm{Ya}$ & $78 \%$ \\
\hline & & Tidak & $22 \%$ \\
\hline
\end{tabular}

Dari profil responden diatas menunjukkan bahwa salah satu penunjang dalam pembelajaran daring yaitu kepemilikan smartphone dan laptop. Hasil menunjukkan bahwa seluruh responden memilki smartphone tetapi hanya $78 \%$ yang memiliki laptop. Hal ini menunjukkan ada sedikit kendala dalam merespon pembelajaran dari dosen melalui video. Pembelajaran statistic ini 100\% menggunakan analisis yang dibantu oleh excel dan SPSS. Dari 
mahasiswa yang tidak memiliki laptop maka dosen pengampu mata kuliah memberi kesempatan untuk belajar bersama ataupun mengolah data secara manual.

Untuk mengukur respon mahasiswa terhadap pembelajaran daring berbasis video ini menggunakan skala berikut.

Tabel 3. Kategori Penilaian

\begin{tabular}{llll} 
No & Rentang Skor & Kategori & Hasil \\
1 & $\mathrm{M}>\left(\mathrm{Mi}+1,5^{*} \mathrm{Sbi}\right.$ & Sangat Baik & $>4$ \\
2 & $(\mathrm{Mi}+0,5 * \mathrm{Sbi})<\mathrm{M} \leq(\mathrm{Mi}+1,5 \mathrm{SBi}$ & Baik & $3,3<\mathrm{M} \leq 4$ \\
3 & $(\mathrm{Mi}-0,5 * \mathrm{Sbi})<\mathrm{M} \leq(\mathrm{Mi}+0,5 \mathrm{SBi}$ & Cukup & $2,67<\mathrm{M} \leq 3,3$ \\
4 & $(\mathrm{Mi}-1,5 * \mathrm{Sbi})<\mathrm{M} \leq(\mathrm{Mi}-0,5 \mathrm{SBi})$ & Kurang & $2<\mathrm{M} \leq 2,67$ \\
5 & $\mathrm{M} \leq(\mathrm{Mi}-1,5 * \mathrm{Sbi}$ & Sangat Kurang & $\leq 2$ \\
\hline
\end{tabular}

Dari hasil respon mahasiswa menunjukkan hasil dari beberapa indicator yaitu: dari aspek materi menunjukkan hasil 3,83 dan 3,72 yaitu baik untuk kategori penggunaan bahasa yang komunikatif dan contoh analisis data. Video pembelajaran yang digunakan dalam menyampaikan tutorial SPSS ini sangat komunikatif untuk berinteraksi dengan mahasiswa sehingga menunjukkan kemudahan mahasiswa dalam mempraktikkan analisis data dengan SPSS.

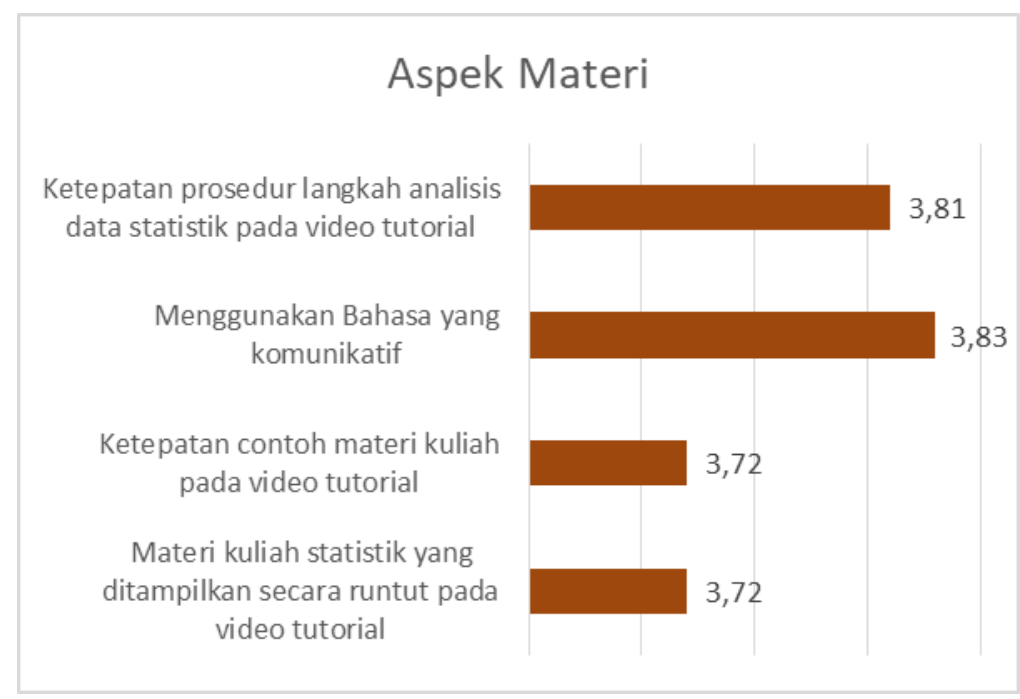

Gambar 1. Penilaian Aspek Materi

Aspek berikutnya yaitu kesesuaian video baik dengan prosedur, kualitas audio maupun gambar pada video tutorial. Hasil menunjukkan bahwa respon mamahssiswa terkait dengan memahami prosedur materi statistic menunjukkan kategori cukup dengan nilai 3,26. Selain itu kejelasan materi dalam video tersebut masih kategori cukup dengan nilai 3,47. Mahasiswa masih belum terbiasa dengan penyajian materi dalam bentuk video tutorial. Berikut hasil respon mahasiswa terkait kesesuaian video dengan konten materi. 


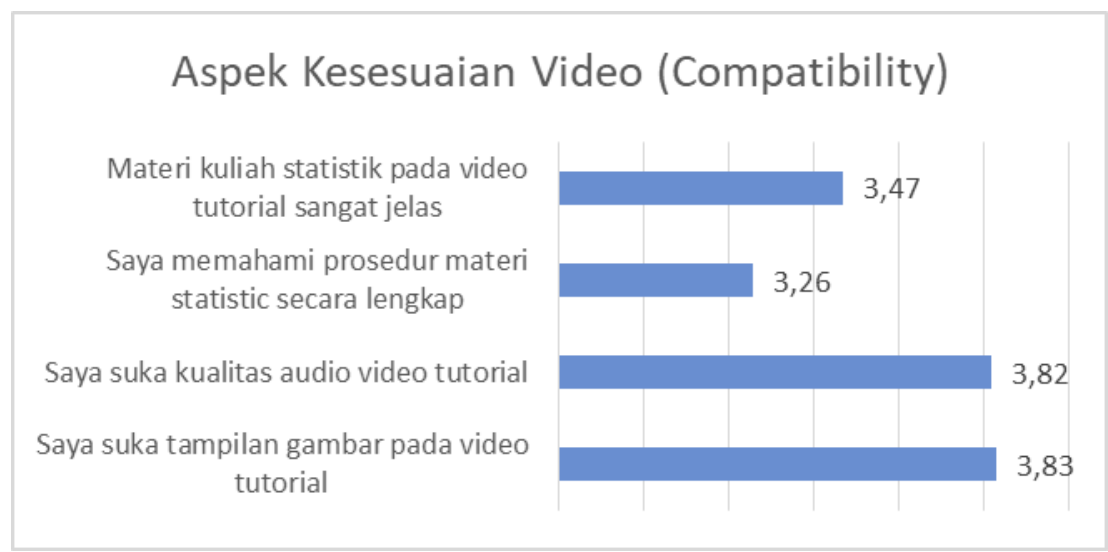

Gambar 2. Penilaian aspek Kesesuaian Video

Video tutorial ini sangat mudah digunakan dalam pembelajaran statistic, karena media video pembelajaran ini sangat mudah digunakan dalam praktikum analisis data penelitian. Berikut hasil untuk penilaian mahasiswa terhadap kompleksitas tampilan video pembelajaran, nilai menujukkan 3,64 untuk kategori penilaian kemudahan penggunaan video pembelajaran ini. Selain itu dalam mempelajari analisis data dengan menggunakan video ini menunjukkan nilai cukup dengan nilai 3,1 pada kategori permasalahan pada praktikum analysis data. Pembelajaran ini untuk pertama kalinya yaitu pembelajaran statistic berbantuan video karena biasanya praktikum mahasiswa langsung belajar dengan dosen di laboratorium computer. Adanya pandemic covid-19 ini memang benar-benar memberikan kebebasan kita dalam belajar. Berikut hasil penilaian pada aspek kompleksitas.

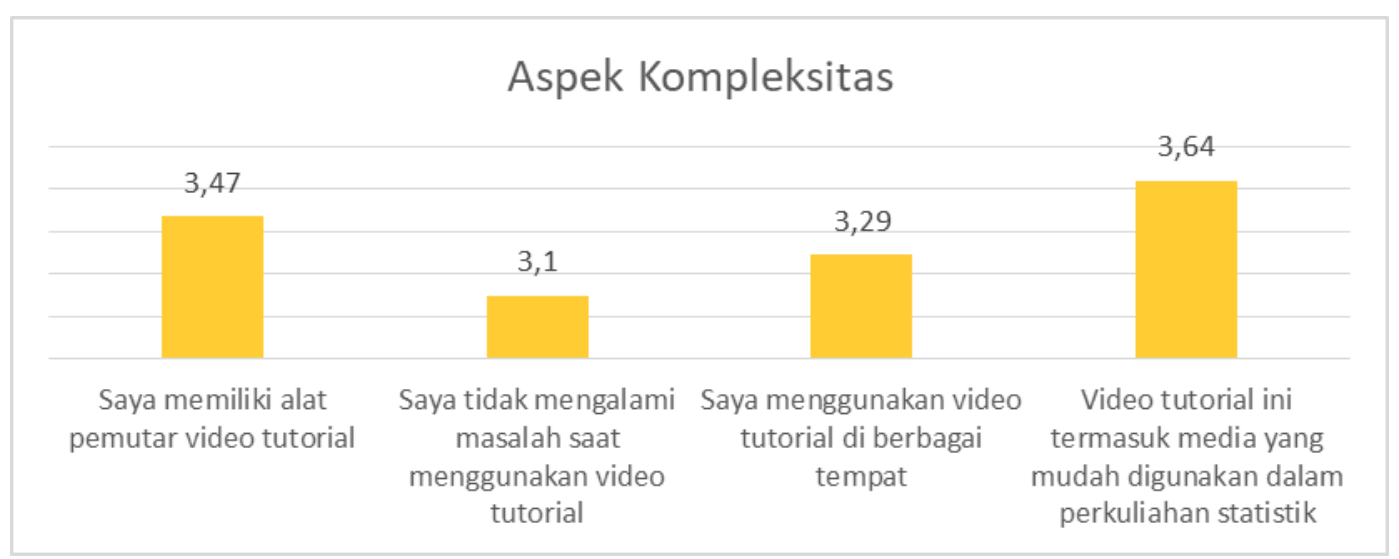

\section{Gambar 3. Penilaian aspek Kompleksitas}

Ketercobaan penggunaan video pembelajaran ini menunjukan kategori baik dalam penggunaan video secara berulang-ulang untuk memahami proses analisis data dengan spss dengan nilai respon mahasiswa yaitu 3,85. Respon mahasiswa menunjukkan bahwa baik pada kategori. Karena penggunaan video pembelajaran ini merupakan hal yang pertama dilakukan selama perkuliahan jadi belum terbiasa dengan pembelajaran rekaman video. 


\section{Aspek Triability}

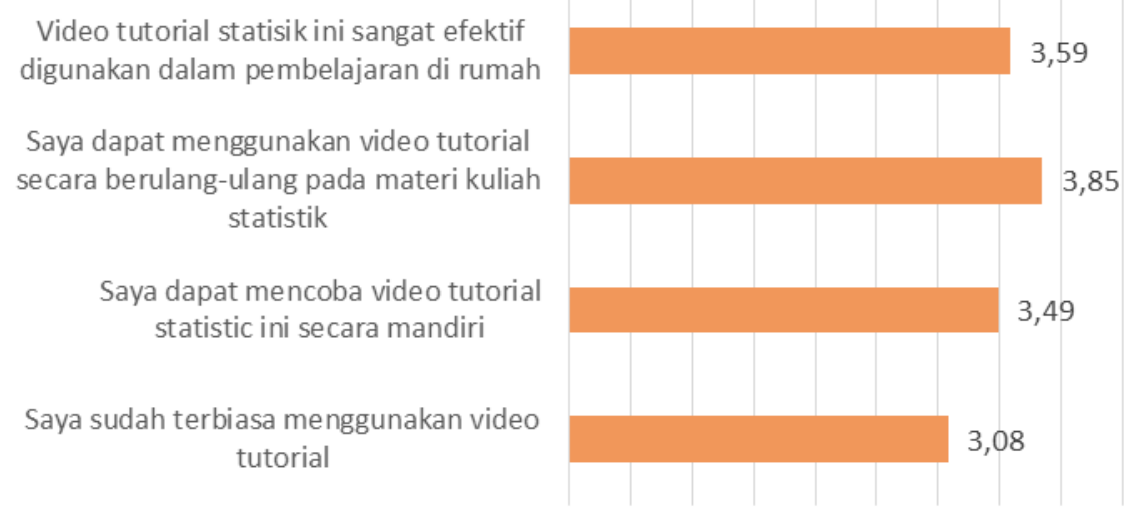

\section{Gambar 4. Penilaian aspek Triability}

Aspek kebermanfaatan sangatlah penting dalam implementasi penggunaan video pembelajaran, dari hasil respon mahasiswa menunjukkan nilai 3,7 kategori baik. Adanya video ini dapat membant mahasiswa dalam mengerjakan tugas, membantu belajar mandiri dan meningkatkan pemahaman praktikum analisis data dengan menggunakan spss. Berikut nilai respon mahasiswa aspek kebrmanfaatan penggunaan video pembelajaran pada mata kuliah statistic.

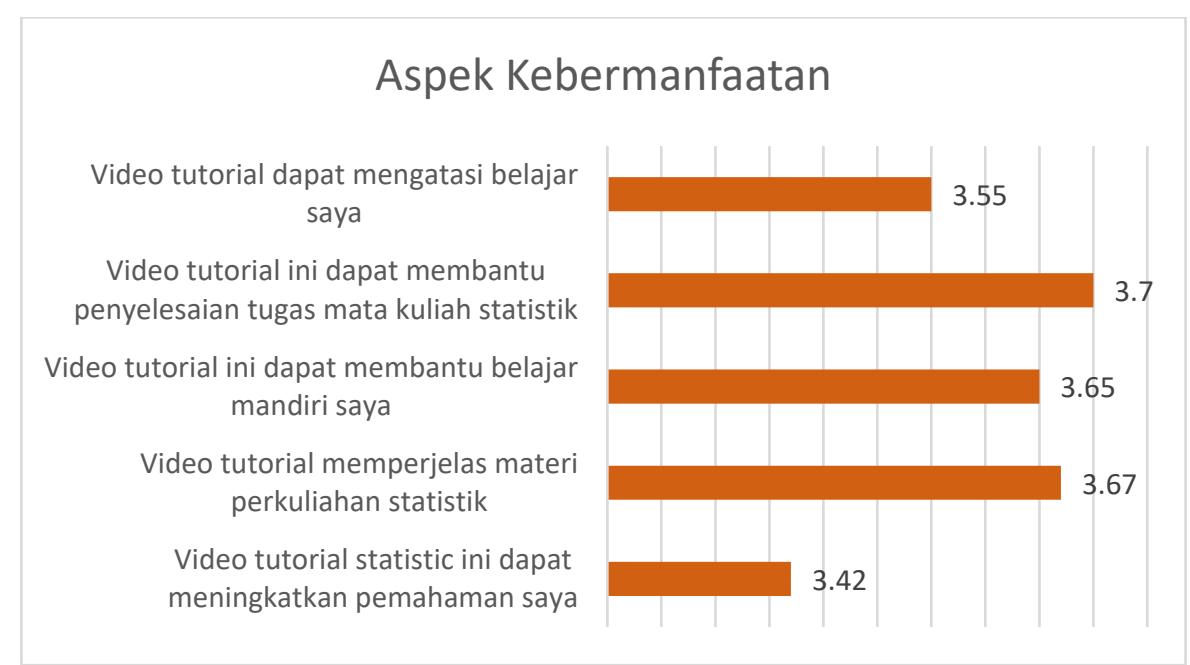

Gambar 5. Penilaian aspek Kebermanfaatan

Rata-rata penilaian respon mahasiswa terhadap penggunaan video pembelajaran ini yaitu: Aspek materi menunjukkan nilai 3,77 dengan kategori baik, aspek compatibility menunjukkan nilai 3,59 dengan kategori baik, untuk aspek kompleksitas menunjukkan nilai 3,38 dengan kategori cukup, untuk aspek triability menunjukkan hasil 3,51 dengan kategori baik sedangkan aspek kebermanfaatan menunjukkan nilai 3,6 dengan kategori baik. 


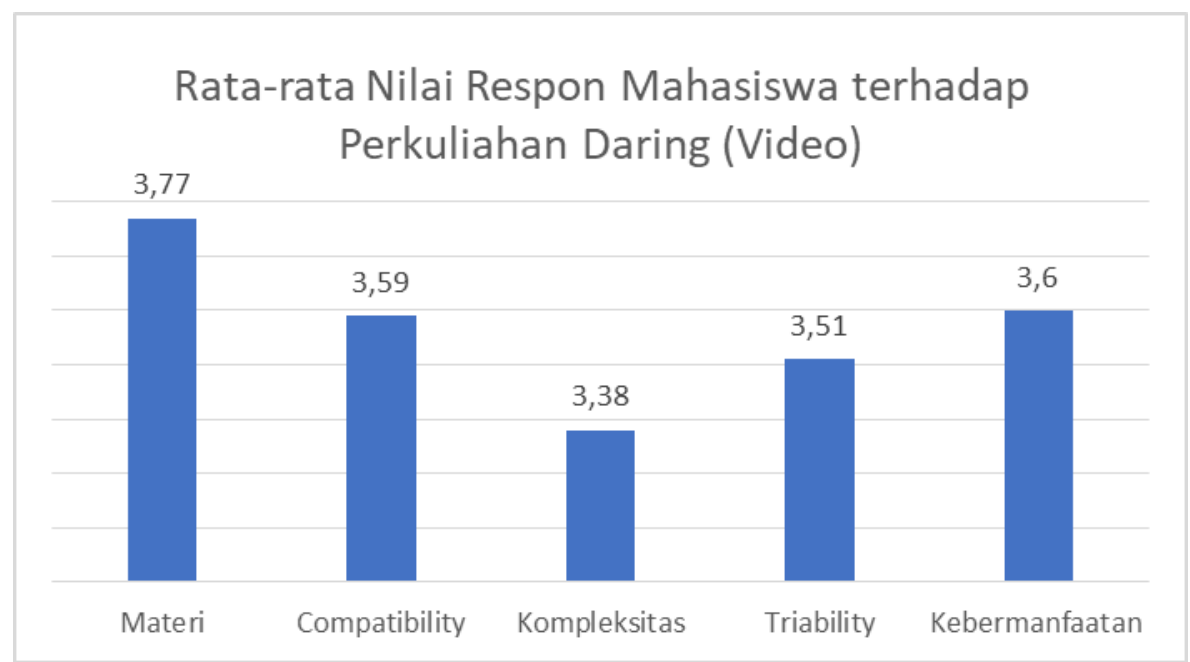

Gambar 6. Rata-Rata Nilai Respon Mahasiswa Terhadap Perkuliahan Daring Berbasis Video

\section{PEMBAHASAN}

Hasil penelitian ini merupakan implementasi pembelajaran daring pada mata kuliah statistic pendidikan untuk analisis data penelitian. Untuk menghadapi pembelajaran daring kali ini mahasiswa membutuhkan persiapan yang matang karena tidak terbiasa belajar tanpa ketemu dosen. Pembelajaran daring dituntut untuk belajar mandiri dan membiaskan aspek social, sedangkan belajar tatap muka dapat berinteraksi dengan rekan mahasiswa ataupun dengan dosen. Dalam penelitian (Maulana \& Iswari, 2020) menunjukkan bahwa adanya perubahan tersebut dapat mempengaruhi tingkat stress dalam menghadapi pembelajaran daring, tetapi mahasiswa mulai beradaptasi dengan keadaan sehingga tingkat stress mahasiswa menunjukkan kriteria 52\% dalam kategori normal mengahadapi masa seperti ini dalam pembelajaran (Maulana \& Iswari, 2020). Pembelajaran daring ini salah satu bentuk pemanfaatan IT yang membutuhkan ketelitian dan mengontrol kendali diri untuk belajar mandiri untuk memperoleh informasi, pengembangan diri dengan memahami dirinya sendiri. Pembelajaran daring sangat membutuhkan berbagai strategi dalam penyampaian virtual. Untuk pertama kalinya pembelajaran statistic ini dengan menggunakan video sebagai upaya untuk membantu mahasiswa dalam tutorial praktikum analisis data penelitian sesuai dengan capaian pembelajaran mata kuliah statistic. Hal ini selaras dengan penelitian (Mustakim, 2020) menunjukkan bahwa efektivitas pembelajaran daring pada mata pelajaran matematika $23,3 \%$ menjawab sangat efektif dilakukan dengan media online yaitu menggunakan video call, mengirim video dengan durasi yang agak singkat untuk meminimalisir kuota, penggunaan bahasa yang komunikatif dalam menyampaikan materi, serta penjadwalan dalam pemberian tugas.

Kemampuan kognitif dalam menyelesaikan soal-soal statistic bukan hanya dibutuhkan level kognitif knowledge (C1) tetapi sampai pada penerapan konsep. Hal ini dibuktikan dalam hasil penelitian (Nuraeni et al., 2020) menyatakan dalam kemampuan pemhaman kognitif pembelajaran matematika tidak hanya menghafal tetapi pada penerapan teori dalam bentuk menyelesaikan tugas secara bertahap dalam matematika. Dalam penelitian lain mengungkapkan bahwa kemampuan mengapilkasikan konsep sangat rendah karena siswa belum memahami konsep yang akan di terapkan dalam analisis data penelitian (Yanti, RidaAdhari., Nindiasari, 2020). Oleh karena itu pemahaman konsep matematis ataupun statistic paling utama dalam menyelesaikan permasalahan perhitungan.

Ada beberapa alasan mahasiswa menyukai penyampaian materi tutorial statistic ini dengan menggunakan video yaitu : (1) mudah digunakan, (2) dapat digunakan berulang-ulang, (3) Jelas dalam tahapan analisis data, (4) membuat pembelajaran lebih santai dalam artian merdeka belajar. Pembelajaran daring dengan penggunaan digital learning ecosystem ini 
memberikan kebermanfaatan bagi mahasiswa untuk mempersiapkan merdeka belajar sehingga mahasiswa diberikan keleluasaan untuk mengeksplor materi, mengkritis dari materi yang telah disampaikan, mengakomodasi gaya belajar, fleksibilitas dan pengalaman belajar dapat memberikan kesan postif oleh mahasiswa (Oktavian \& Aldya, 2020).

Implementasi pembelajaran daring dengan menggunakan video kali ini mahasiswa ada hambatan dari hasil respon mahasiswa, belum terbiasa praktikum hanya melalui video. Praktikum analisis data kali ini biasanya dilakukan oleh dosen pengampu dengan langsung mempraktikkan di laboratorium computer. Hal ini sejalan dengan penelitian Muhammad Arie (Firmansyah, 2017) menunjukkan bahwa dalam mempelajari statitik pada umumnya terletak pada kemampuan mendasar yaitu kelemahan pada konsep. Kesalahan tersebut bermula pada ketrampilan proses, kesalahan mamahami soal ataupun menggunakan notasi. Untuk mengatasi hambatan tersebut maka digunakan strategi pembelajaranagar mahasiswa lebih terasah kemampuan berfikir serta memberikan soal-soal yang bervariatif. Begitu juga penemuan oleh peneliti oleh (Annur \& Hermansyah, 2020) meyatakan bahwa ada beberapa kendala dalam pembelajaran matematika daring kesulitan teknis terkait signal, kesulitan adaptasi bagi mahasiswa masih belum siap untuk kuliah daring, terbatasnya kemampuan dosen dalam menyampaikan materi dengan berbagai aplikasi.

Komentar dari mahasiswa terhadap implementasi pembelajaran daring dengan video yaitu : (1) terbatasnya sinyal dan kekurangan kuota menjadi kendala dalam mengunduh video, (2) kurang memahami materi karena dibatasi oleh tempat (hanya dilakukan dengan virtual), (3) Lebih mudah jika dilakukan praktikum langsung dengan tatap muka bersama dosen pengampu. Hal ini terbukti juga dalam penelitian (Anugrahana, 2021) pembelajaran faktor analisis kesulitan belajar matematika atau statistic yaitu dilihat secara teknis dan pemahaman konsep mahasiswa. Oleh karena itu dalam pembelajaran daring ini perlu adakan evaluasi untuk peningkatan atau perbaikan dalam menyampaikan pembelajaran.

\section{SIMPULAN DAN SARAN}

Berdasarkan hasil penelitian menunjukkan bahwa penggunaan video pembelajaran ini merupakan strategi yang digunakan pada masa pandemic covid-19, dengan adanya video ini sebagai upaya untuk memberi materi dalam bentuk tutorial video mempraktikkan analisis data pada mata kuliah statistic. Video tutorial ini memuat proses analisis data mulai dari pemahaman materi melalui ringkasan PPT, input data dengan contoh, analisis dengan spss sampai dengan meringkas hasil analisis data.

Hasil respon mahasiswa menunjukkan secara umum imlementasi pembelajaran daring dengan menggunakan video yaitu aspek materi 3,77 (baik), aspek compatibility 3,59 (baik), kompleksitas 3,38 (cukup), aspek triability 3,51 (baik) dan aspek kebermanfaatan 3,6 (baik).

\section{ACKNOWLEDGMENTS}

Pada kesempatan ini kami ucapkan terimaksih pada berbagai pihak terlaksananya penelitian ini. Pertama, Dekan Fakultas Tarbiyah dan Ilmu Keguruan yang telah memberi kesempatan pada kami sehingga penelitian berjalan denganlancar dan sukses. Kedua, Mahasiswa Unisnu Jepara yang berpartisipasi aktif dalam kegiatan penelitian. Harapannya dengan penelitian ini memberi wacana bahwa tidak meresahkan adanya pembelajaran daring sehingga menumbuhkan kreativitas guru ataupun siswa dalam pembelajaran.

\section{DAFTAR RUJUKAN}

Annur, M. F., \& Hermansyah. (2020). Analisis Kesulitan Mahasiswa Pendidikan Matematika dalam Pembelajaran Daring pada Masa Pandemi Covid-19. Jurnal Kajian, Penelitian Dan Pengembangan Kependidikan, 11, 195-201.

Anugrahana, A. (2021). Analisis Kemampuan Pemahaman Kognitif Dan Kesulitan Belajar Matematika Konsep "Logika” Dengan Model Pembelajaran Daring. Scholaria: Jurnal Pendidikan Dan Kebudayaan, 11(1), 37-46. https://doi.org/10.24246/j.js.2021.v11.i1.p37-46 
Batubara, H. H., \& Ariani, D. N. (2019). Model Pengembangan Media PembelajaranAdaptif Di Sekolah Dasar. Muallimuna: Jurnal Madrasah Ibtidaiyah, 5(1), 33-46.

Bilfaqih. (2015). Esensi Pengembangan Pembelajaran Daring. Deepublish.

Firmansyah, M. A. (2017). Analisis Hambatan Belajar Mahasiswa Pada Mata Kuliah Statistika. Jurnal Penelitian Dan Pembelajaran Matematika, 10(2). https://doi.org/10.30870/jppm.v10i2.2036

Haryadi, R., Vita, M., Utami, I. S., Ihsanudin, I., Setiani, Y., \& Suherman, A. (2019). Briquettes production as teaching aids physics for improving science process skills. Journal of Physics: Conference Series.

Irsyad, T., Wuryandini, E., Yunus, M., \& Hadi, D. P. (2020). Analisis Keaktifan Mahasiswa dalam Proses Pembelajaran Statistika Mulitvariat. Jurnal Pendidikan Ekonomi Undiksha, 12(1), 89. https://doi.org/10.23887/jjpe.v12i1.24294

Maulana, H. A. \&, \& Iswari, R. D. (2020). Analisis Tingkat Stres Mahasiswa Terhadap Pembelajaran Daring Pada Mata Kuliah Statistik Bisnis di Pendidikan Vokasi. Jurnal Ilmiah Kependidikan, 14(1), 17-30.

Mustakim. (2020). Efektivitas Pembelajaran Daring Menggunakan Media Online Selama Pandemi Covid-19 Pada Mata Pelajaran Matematika the Effectiveness of E-Learning Using Online Media During the Covid-19 Pandemic in Mathematics. Al Asma: Journal of Islamic Education, 2(1), 1-12.

Nuraeni, D., Azwar Uswatun, D., \& Nurasiah, I. (2020). Analisis Pemahaman Kognitif Matematika Materi Sudut Menggunakan Video Pembelajaran Matematika Sistem Daring Di Kelas Iv B Sdn Pintukisi. Pendas : Jurnal Ilmiah Pendidikan Dasar, V(Vol 5 No 1 June 2020), 61-75. https://doi.org/10.23969/jp.v5i1.2915

Oktavian, R., \& Aldya, R. F. (2020). Efektivitas Pembelajaran Daring Terintegrasi di Era Pendidikan 4.0. Didaktis: Jurnal Pendidikan Dan Ilmu Pengetahuan, 20(2), 129-135. https://doi.org/10.30651/didaktis.v20i2.4763

Pakpahan, R., \& Fitriani, Y. (2020). Analisa Pemanfaatan Teknologi Informasi dalam Pembelajaran Jarak Jauh di Tengah Pandemi Virus Corona Covid-19. Journal of Information System, Applied, Management, Accounting and Research, 4(2), 30-36.

Utomo, A. Y. . D. R. (2018). Pengembangan Vidio Tutorial Dalam Pembelajaran Sistem Pengapian di SMK. Taman Vokasi, 6(1), 68-76. http://jurnal.ustjogja.ac.id/index.php/tamanvokasi

Yanti, RidaAdhari., Nindiasari, I. (2020). Analisis Kemampuan Pemahaman Konsep Matematis Mahasiswa. Jurnal Wilangan, 1(3), 245-256. https://doi.org/10.24952/logaritma.v7i01.1669 